Discussion Paper 129

Institute for Empirical Macroeconomics

Federal Reserve Bank of Minneapolis

90 Hennepin Avenue

Minneapolis, Minnesota 55480-0291

March 1999

\title{
Entrepreneurial Moral Hazard and Bank Monitoring: A Model of the Credit Channel
}

\author{
Rafael Repullo and Javier Suarez*
}

CEMFI and CEPR

\begin{abstract}
This paper develops a model of the choice between bank and market finance by entrepreneurial firms that differ in the value of their net worth. The monitoring associated with bank finance ameliorates a moral hazard problem between the entrepreneurs and their lenders. The model is used to analyze the different strands of the credit view of the transmission of monetary policy. In particular, we derive the empirical implications of a broad credit channel, and compare them to those obtained when the model is extended to incorporate some elements of the bank lending channel.

*We would like to thank Patrick Bolton, Denis Gromb, John H. Moore, Oren Sussman, and three anonymous referees for helpful comments. The views expressed herein are those of the authors and not necessarily those of the Federal Reserve Bank of Minneapolis or the Federal Reserve System.
\end{abstract}




\section{Introduction}

It is widely accepted that monetary authorities can affect real economic activity through changes in short-term interest rates. The traditional money view relies on the sensitivity of spending to interest rates as predicted by the standard theories of consumption and investment under perfect capital markets. In contrast, the credit view stresses that monetary policy affects the economy through its impact on borrowers' access to credit, especially bank loans.

Recent research places financial imperfections at the center of the credit channel for monetary transmission. It is now known that informational problems can create a wedge between the costs of external and internal funds to firms. Investment projects that are worth undertaking under internal finance may be unprofitable (or less profitable) if the required funds have to be raised externally. Financial variables such as net worth or the amount of preexisting debt influence the costs of external funds, and hence generate a mechanism that links financial factors to the level of economic activity. $^{1}$

One can distinguish two related strands of this literature. The first one, known as the broad credit channel, focuses generically on the implications of financial imperfections for the transmission of monetary shocks, stressing that their impact on individual borrowers depends on the strength of their balance sheets. The second one, called the bank lending channel, highlights the importance that imperfections related to the banks' intermediary function have for monetary transmission. Interest rate and capital regulations, as well as the banks' own balance sheet positions are among the suspects behind this second channel.

The conceptual distinction between these two channels has driven much of the empirical discussion. However, the lack of a theoretical formalization that encompasses both of them makes it difficult to identify a set of testable implications whereby they can be empirically distinguished. This paper attempts to fill this gap.

We analyze the two strands of the credit view using a microeconomic model of entrepreneurial firms' financing. In this model, firms have access to an investment project of fixed size. Each firm is characterized by the size of its project and the

\footnotetext{
${ }^{1}$ See Bernanke and Gertler (1989), Greenwald and Stiglitz (1993), Kiyotaki and Moore (1997), and Suarez and Sussman (1997).
} 
amount of internal funds available for undertaking it. Some firms require external finance and there is a moral hazard problem between the entrepreneurs and their financiers, because the former can divert project resources towards private uses.

There are two modes of external finance: market finance and bank finance. Building on the financial intermediation literature, we assume that bank finance involves a higher monitoring intensity than market finance, which ameliorates the entrepreneurial moral hazard problem. We show that in equilibrium the set of firms can be divided according to the value of their net worth ratio (the ratio of their internal funds to the investment required by their projects) into three different groups. Firms with large net worth prefer market lending, firms with intermediate net worth get bank lending, and firms with little net worth are unable to obtain credit.

A number of comparative statics results are then derived. In particular, it is examined how aggregate investment, the quantities of market and bank lending, and the equilibrium interest rate spreads shift with changes in the riskless rate, which is taken to be an indicator of the stance of monetary policy. These results are broadly consistent with the evidence documented, among others, by Stock and Watson (1989), Friedman and Kuttner (1992), Gertler and Gilchrist (1993), and Bernanke, Gertler and Gilchrist (1996). However, they cannot accommodate an increase in market lending (commercial paper) following a monetary contraction, which accords with the interpretation by Kashyap, Stein and Wilcox (1993) that such behavior may reflect the operation of a bank lending channel.

Next we extend the model to incorporate some of the specificities of banks. We adopt a minimal approach that focuses on two important legal constraints which affect (or have affected until recently) the provision of bank lending: deposit interest rate ceilings and capital requirements. We find that the behavior of market lending documented in Kashyap, Stein and Wilcox (1993) is easy to explain under interest rate ceilings, but not under capital requirements, unless one assumes that monetary shocks impact significantly on bank capital.

The literature on the credit channel is surveyed in Gertler (1988), Kashyap and Stein (1994), and Hubbard (1995). The formalizations by Bernanke and Blinder (1988), Romer and Romer (1990), Friedman and Kuttner (1993a), and Kashyap, Stein and Wilcox (1993) are extensions of the standard IS/LM model that, under 
assumptions of imperfect substitutability, allow for the coexistence of "bonds" and "bank loans". In contrast to this reduced-form approach, we derive the choice between market and bank finance from first principles. Moreover, by explicitly allowing for firm heterogeneity, we can account for some of the evidence on the cross-sectional impact of monetary policy (Gertler and Gilchrist, 1994; Oliner and Rudebusch, 1996b).

Several previous papers have modeled the choice between market and bank finance by considering an entrepreneurial moral hazard problem that can be ameliorated through (costly) bank monitoring. Diamond (1991) examines the interactions between reputational capital (a good track record) and monitoring, delivering the implication that the typical bank borrowers will be the entrepreneurs with intermediate credit ratings. Besanko and Kanatas (1993) provide a rationale for mixed finance by considering a model in which entrepreneurs may suffer from "excessive monitoring" by their banks, and mitigate this problem by partially relying on market finance. However, neither paper focuses on the implications for monetary policy transmission and their models are either too complicated or not flexible enough for that purpose. The paper most closely related to ours is by Holmstrom and Tirole (1997), who examine the role of net worth when both entrepreneurs and banks are subject to moral hazard problems vis-a-vis their respective lenders. However, we abstract from incentive problems at the level of banks, consider a slightly more flexible decision problem at the level of entrepreneurs (which generates greater dispersion in borrowing rates), and focus our discussion on the effects of monetary shocks rather than shocks to entrepreneurial or bank net worth.

The paper is organized as follows. Section 2 presents the basic model of lending under moral hazard. Section 3 characterizes the optimal choice between market finance and bank finance. Section 4 analyzes the broad credit channel, and Section 5 accounts for the bank lending channel by extending the analysis to situations where banks are subject to interest rate ceilings and capital requirements. Section 6 concludes. 


\section{A Model of Lending under Moral Hazard}

Consider an economy with two dates $(t=0,1)$ and a continuum of risk-neutral entrepreneurs. Each entrepreneur is characterized by her initial wealth $W$ and by the size $I$ of the investment required by an indivisible project that she may start up at $t=0$. Let $\theta=W / I$ denote the entrepreneur's net worth ratio, i.e. the ratio of her initial wealth to the investment required by her project. The set of entrepreneurs in the economy is then described by a cumulative distribution function $F(\theta, I)$.

Each started project yields at $t=1$ a combination of verifiable random cash flows and nonverifiable private benefits for the entrepreneur. If the entrepreneur wants to increase her private benefits, she has to divert resources from the project towards private uses, thereby reducing the expected cash flows. Denoting the entrepreneur's decision on how the project is run by $p \in[0,1]$, we assume that the cash flow of a project of size $I$ is $A I>0$ with probability $p$ (success) and 0 with probability $1-p$ (failure). In addition, regardless of the realization of cash flow, private benefits for the entrepreneur are $\varphi(p) A I$, where the function $\varphi(p)$ is decreasing and concave.

Entrepreneurs maximize their expected income at $t=1$, which includes the private benefits obtained from their projects. They have access to a capital market where the (gross) interest rate is $R \geq 1 .^{2}$ So they can invest their wealth either in their own projects or at the market interest rate $R$, and they can also raise external funds for their projects by promising the lenders an expected rate of return of at least $R$.

We assume that the decision on $p$ is not contractible, so the relationship between entrepreneurs and their lenders is subject to moral hazard. The presence of moral hazard introduces an incentive cost that renders net worth relevant to the financing problem. Entrepreneurs with $\theta \geq 1$ have sufficient wealth to circumvent the problem by self-financing their projects. In contrast, those with $\theta<1$ have to rely on external finance. In what follows we will restrict attention to entrepreneurs in the latter class.

We make the following assumptions:

Assumption $1 \varphi(p)=\frac{1}{2 \lambda}\left(1-p^{2}\right)$, with $0<\lambda<1$.

Assumption $2 \frac{8}{7}<\frac{\lambda A}{R}<4$.

\footnotetext{
${ }^{2} R$ will be later identified with the interest rate set by a monetary authority.
} 
Assumption 1 establishes a functional form for $\varphi(p)$ that will enable us to solve the model explicitly. ${ }^{3}$ Identical qualitative results might be obtained in this section under a general decreasing and concave $\varphi(p)$. The differences would arise when introducing market and bank finance in the next section, since some details of the comparison between them (and, especially, the comparative statics) would become intractable. ${ }^{4}$ Assumption 2 states that the profitability of the projects (measured by parameter $A$ ) is neither too small nor too large relative to the opportunity cost of funds $R$. Together with Assumption 1, this will ensure that investment is viable for some entrepreneurs but not for all of them. ${ }^{5}$

To start examining the problem of external finance under moral hazard, suppose that an entrepreneur with initial wealth $W$ and a project of size $I$ borrows $I-W$ at a given (gross) borrowing rate $B{ }^{6}$ She will then choose $p$ in order to maximize her utility

$$
p[A I-B(I-W)]+\varphi(p) A I=\{p[A-B(1-\theta)]+\varphi(p) A\} I .
$$

This expression reflects that with probability $p$ the project succeeds, in which case it yields cash flow $A I$ and the entrepreneur pays $B(I-W)$ to the lender, and with probability $1-p$ the project fails, in which case neither the entrepreneur nor the lender receive any cash. It also reflects that, no matter whether the project succeeds or fails, the entrepreneur gets the private benefits $\varphi(p) A I$.

Lenders observe both the initial wealth and the size of the project of each entrepreneur, and correctly anticipate her decision $p$ under each borrowing rate $B$. Thus the lowest $B$ for which they are willing to participate in funding a given project satisfies

$$
p B=R,
$$

where $p$ is the probability of success that the corresponding entrepreneur is expected to choose.

\footnotetext{
${ }^{3}$ Note that with this functional form the total expected return of the project (including the private benefits), $[p+\varphi(p)] A I$, is maximized for $p=\lambda<1$. Hence some amount of private benefits is first-best optimal.

${ }^{4}$ We further comment on this after Proposition 2 below.

${ }^{5}$ The amount $\lambda A / R$ is the present value of the cash flow of a project of unit size under the firstbest probability of success $p=\lambda$. Hence Assumption 2 implies that, in the absence of moral hazard, all projects would have positive net present value.

${ }^{6}$ Proposition 1 below proves that this instance of maximum inside equity participation is indeed optimal.
} 
We can now state the main result of this section.

Proposition 1 There exists a critical value $\bar{\theta} \in(0,1)$ such that borrowing is not feasible for entrepreneurs with net worth ratio $\theta<\bar{\theta}$. The optimal contract for an entrepreneur with $\bar{\theta} \leq \theta<1$ is to borrow $I-W$ at an interest rate $B(\theta)=R / p(\theta)$, where

$$
p(\theta)=\frac{\lambda}{2}\left[1+\left(\frac{\theta-\bar{\theta}}{1-\bar{\theta}}\right)^{1 / 2}\right]
$$

is the corresponding probability of success. The expected utility of an entrepreneur with a project of size $I$ and a net worth ratio $\theta \geq \bar{\theta}$ is given by $u(\theta) I$, where

$$
u(\theta)=\frac{1}{2}[A p(\theta)-R(1-\theta)]+\frac{A}{2 \lambda} .
$$

Proof Using Assumption 1, the entrepreneur's maximization of (1) yields the firstorder condition $A-B(1-\theta)=A p / \lambda$. Substituting $B=R / p$ from (2) into this condition gives the quadratic equation $A p^{2}-\lambda A p+\lambda R(1-\theta)=0$. This equation has real solutions if $\theta \geq \bar{\theta}$, where

$$
\bar{\theta}=1-\frac{\lambda A}{4 R}
$$

Clearly $\bar{\theta}<1$, and by Assumption 2 we also have $\bar{\theta}>0$. For $\theta>\bar{\theta}$ the quadratic equation has two roots, but the entrepreneur prefers the largest one (the root associated with the lowest $R$ ), which is (3). Substituting $B=R / p$ and $A p^{2}=\lambda A p-\lambda R(1-\theta)$ into the entrepreneur's objective function gives (4). To prove that entrepreneurs with $\theta \geq \bar{\theta}$ want to invest all their wealth in their project rather than some or all of it at the interest rate $R$, consider first those with $\theta=\bar{\theta}$. For them investing $W=\bar{\theta} I$ in the project is necessary for viability, so we simply need to check that $u(\bar{\theta}) I \geq R \bar{\theta} I$. By (4) and (5), this inequality reduces to

$$
\frac{\lambda A}{R} \geq\left(\frac{3}{8}+\frac{1}{2 \lambda^{2}}\right)^{-1},
$$

which holds by Assumption 2. ${ }^{7}$ Given this, entrepreneurs with $\theta>\bar{\theta}$ will also want to invest at least $\bar{\theta} I$ in their projects. Furthermore investing wealth in excess of $\bar{\theta} I$ in the project yields a marginal utility greater than the interest rate $R$ :

$$
\frac{d}{d W}[u(\theta) I]=\frac{R}{2}\left[1+\left(\frac{1-\bar{\theta}}{\theta-\bar{\theta}}\right)^{1 / 2}\right]>R .
$$

\footnotetext{
${ }^{7}$ Note that if $\lambda^{2} \leq 4 / 5$ the lower bound in Assumption 2 could be reduced to 1 .
} 
Hence devoting all entrepreneurial wealth to the project is indeed optimal.

Proposition 1 shows that entrepreneurs with a net worth ratio $\theta<\bar{\theta}$ will be unable to raise external funds and to start up their projects. On the other hand, those with $\theta \geq \bar{\theta}$ will invest all their wealth $W$ in their projects and raise the difference $I-W$ externally. Their probability of success is given by the function $p(\theta)$, which is increasing and strictly concave, and satisfies $p(\bar{\theta})=\lambda / 2$ and $p(1)=\lambda$. Correspondingly, the function $B(\theta)=R / p(\theta)$, that describes the gross borrowing rate charged to them, is decreasing and strictly convex, and satisfies $B(\bar{\theta})=2 R / \lambda$ and $B(1)=R / \lambda$. These results reflect that the entrepreneurs' net worth ratio $\theta$ has a positive incentive effect (measured by $p^{\prime}(\theta)>0$ ) which becomes less important as $\theta$ approaches the self-financing threshold of 1 .

The properties of $p(\theta)$ imply that the utility of the entrepreneurs that are able to start their projects, $u(\theta) I$, is increasing and strictly concave in $\theta$. Moreover, as shown in (6), the marginal utility of entrepreneurial wealth is greater than $R$, reflecting that internal financing ameliorates the moral hazard problem. For this reason, entrepreneurs find it optimal to invest all their wealth in their projects.

\section{Market Finance and Bank Finance}

In this section we compare two alternative modes of funding the investment projects: market finance and bank finance. We assume that the difference between them relates to the extent to which the corresponding lenders monitor their borrowers in order to ameliorate the moral hazard problem. Thus monitoring in this context means the application by the lender of some external control mechanism that makes the diversion of project resources towards private uses less profitable to the entrepreneur.

The literature widely accepts that publicly traded securities such as commercial paper or corporate bonds ("market finance") typically involve a lower monitoring intensity than bank loans ("bank finance"). The standard argument is that the control of the debtor is less effective in market finance because the dispersion of securityholders generates either free-rider problems or a wasteful multiplication of monitoring costs (Diamond, 1984). Moreover, banks may have better information than ordinary market investors because they are geographically closer to the firms, because they spe- 
cialize in lending to firms of a certain type, because they observe the movements in the firms' bank accounts (Nakamura, 1993), or because they can be trusted with proprietary information that, if public, would benefit the firms' competitors (Bhattacharya and Chiesa, 1995; Yosha, 1995). Also, the nature of short-term bank financing (and refinancing) may be more conducive to the control of certain wasteful activities (Repullo and Suarez, 1997). Given all these reasons, we will associate market finance with a lower level of monitoring than bank finance.

Formally, we account for the difference in monitoring intensities by assuming that under market finance the entrepreneurs' private benefit function (as defined in the previous section) is

$$
\varphi_{m}(p)=\frac{1}{2 \lambda_{m}}\left(1-p^{2}\right)
$$

whilst under bank finance it is

$$
\varphi_{b}(p)=\frac{1}{2 \lambda_{b}}\left(1-p^{2}\right)
$$

where

$$
0<\lambda_{m}<\lambda_{b}<1
$$

Thus $\varphi_{b}(p)<\varphi_{m}(p)$ for all $p<1$, which means that the higher monitoring intensity associated with bank finance reduces the entrepreneurial private benefits obtained under any given probability of success. Furthermore we have $\varphi_{m}^{\prime}(p)<\varphi_{b}^{\prime}(p)<0$ for all $p<1$, which means that increasing the probability of success entails a smaller sacrifice of private benefits under bank finance than under market finance.

The proposed formalization has the advantage of allowing us to apply the analysis developed in the previous section for a general $\lambda$ to the specific cases of market finance $\left(\lambda_{m}\right)$ and bank finance $\left(\lambda_{b}\right)$. From that analysis one can anticipate the main tradeoff for the choice between these two modes of finance. Clearly, for each $p$, the total expected returns of the project are smaller under bank finance than under market finance, which in principle favors the choice of the latter. However, the former has the advantage of weakening the entrepreneur's incentives to take private benefits, which ameliorates the moral hazard problem. This will favor the choice of bank finance, especially if the moral hazard problem under market finance is sufficiently severe.

It is important to note that we are going to use equation (2) to represent the lender's participation constraint under both market and bank finance. This is equiv- 
alent to assuming that banks operate under perfect competition, the opportunity cost of their funds is the market interest rate $R$, and their monitoring activity is costless. In Section 5 we will extend the analysis to a situation in which bank lenders require a higher expected rate of return than market lenders.

Now we are ready to compare the two alternative modes of finance. We will use the subscripts $m$ and $b$ to identify the variables that correspond to market finance and bank finance, respectively.

Proposition 2 The critical values, $\bar{\theta}_{b}$ and $\bar{\theta}_{m}$, below which bank and market finance are not feasible satisfy

$$
0<\bar{\theta}_{b}<\bar{\theta}_{m}<1
$$

In the region where both modes of finance are feasible there exists a critical value $\theta^{*} \in\left[\bar{\theta}_{m}, 1\right)$ such that

$$
u_{m}(\theta) \geq u_{b}(\theta) \text { if and only if } \theta \geq \theta^{*} .
$$

Moreover $p_{m}(\theta)<p_{b}(\theta)$ and $B_{m}(\theta)>B_{b}(\theta)$, for all $\theta \in\left[\bar{\theta}_{m}, 1\right)$.

Proof The inequalities in (10) follow immediately from (5) and (9). To prove (11) first note that (3), (4), and (9) imply

$$
\lim _{\theta \rightarrow 1}\left[u_{m}(\theta)-u_{b}(\theta)\right]=\frac{A\left(\lambda_{b}-\lambda_{m}\right)\left(1-\lambda_{b} \lambda_{m}\right)}{2 \lambda_{b} \lambda_{m}}>0 .
$$

Hence, by continuity, for $\theta$ close to 1 market finance is preferred to bank finance. Next observe that, for $\theta \in\left[\bar{\theta}_{m}, 1\right)$, (4) implies

$$
u_{m}^{\prime}(\theta)-u_{b}^{\prime}(\theta)=\frac{A}{2}\left[p_{m}^{\prime}(\theta)-p_{b}^{\prime}(\theta)\right]
$$

But by (3), (5), and (10) we have

$$
\frac{p_{m}^{\prime}(\theta)}{p_{b}^{\prime}(\theta)}=\left(\frac{1-\bar{\theta}_{m}}{\theta-\bar{\theta}_{m}} \frac{\theta-\bar{\theta}_{b}}{1-\bar{\theta}_{b}}\right)^{1 / 2}>1
$$

Hence $u_{m}(\theta)$ and $u_{b}(\theta)$ have at most one intersection, which together with the previous result implies (11). Finally (9) and (10) imply

$$
p_{m}(\theta)=\frac{\lambda_{m}}{2}\left[1+\left(\frac{\theta-\bar{\theta}_{m}}{1-\bar{\theta}_{m}}\right)^{1 / 2}\right]<\frac{\lambda_{b}}{2}\left[1+\left(\frac{\theta-\bar{\theta}_{b}}{1-\bar{\theta}_{b}}\right)^{1 / 2}\right]=p_{b}(\theta)
$$


and $B_{m}(\theta)=R / p_{m}(\theta)>R / p_{b}(\theta)=B_{b}(\theta)$, for all $\theta \in\left[\bar{\theta}_{m}, 1\right)$

Proposition 2 shows that net worth ratios are critical for the choice between alternative modes of finance. In particular, entrepreneurs with large net worth $\left(\theta \geq \theta^{*}\right)$ prefer market finance, those with intermediate net worth $\left(\bar{\theta}_{b} \leq \theta<\theta^{*}\right)$ get bank finance, and those with little net worth $\left(\theta<\bar{\theta}_{b}\right)$ are unable to fund their projects. Interestingly, $\bar{\theta}_{b}<\bar{\theta}_{m}$, so bank finance is feasible over a wider range of net worth ratios. Consequently, there are entrepreneurs with a real choice between market and bank finance, and there are also some entrepreneurs for whom bank finance is the only feasible mode of finance, but there are no entrepreneurs for whom market finance is the only alternative. Moreover, among the first group, market finance is preferred by those with a higher $\theta$. These features of the model are consistent with the conventional wisdom that the access to (and even the actual use of) arm's-length finance is restricted to the borrowers with the strongest balance sheets. ${ }^{8}$

Figure 1 depicts a case in which the critical value $\theta^{*}$ that divides the regions of bank and market finance is strictly greater than $\bar{\theta}_{m} \cdot{ }^{9}$ Intuitively, when entrepreneurial net worth is high, the moral hazard problem is small, so the incentive advantage of bank finance does not pay for the entailed loss of private benefits. However, as net worth declines, the moral hazard problem worsens, and consequently bank finance becomes comparatively more and more advantageous. Below the critical value $\theta^{*}$, entrepreneurs choose (or have no option but) to finance their projects under bank monitoring.

\section{[INSERT FIGURE 1 HERE]}

The behavior of the equilibrium borrowing rates, $B_{m}(\theta)$ and $B_{b}(\theta)$, is depicted in Figure 2. Both of them are decreasing and convex in $\theta$, and approach $R / \lambda_{m}$ and $R / \lambda_{b}$, respectively, as $\theta$ approaches 1 . Over the interval $\left[\bar{\theta}_{m}, 1\right)$ we have $B_{m}(\theta)>B_{b}(\theta)$, which reflects the positive impact of bank monitoring on the probability of default.

\footnotetext{
${ }^{8}$ Replacing the specific functional forms in (7) and (8) by the assumption that $\varphi_{b}(p)=\beta \varphi_{m}(p)$, with $\varphi_{m}(p)$ decreasing and concave and $\beta<1$, would not change the results, except for the fact that now $u_{m}(\theta)$ and $u_{b}(\theta)$ might intersect more than once. In this case, in some intermediate range $\theta_{b}^{*}<\theta<\theta_{m}^{*}$, with $\bar{\theta}_{b}<\theta_{b}^{*}<\theta_{m}^{*}<1$, one might find an alternating pattern of market and bank finance. Nevertheless entrepreneurs with $\theta>\theta_{m}^{*}$ would still get market finance, those with $\bar{\theta}_{b} \leq \theta<\theta_{b}^{*}$ would get bank finance, and those with $\theta<\bar{\theta}_{b}$ would be unable to fund their projects.

${ }^{9}$ Notice that $\theta^{*}$ may be equal to $\bar{\theta}_{m}$, in which case the entrepreneurs with net worth ratio $\theta^{*}$ may not be indifferent between bank and market finance, but strictly prefer the latter.
} 
Accordingly, the equilibrium borrowing rate exhibits an upward jump at $\theta^{*}$, so the worst market borrowers pay higher interest rates than the best bank borrowers. ${ }^{10}$ Hence, market and bank borrowers are clearly ordered in terms of their net worth ratios, but they are not so in terms of their borrowing rates.

\section{[INSERT FIGURE 2 HERE]}

We conclude this section computing the aggregate quantities of market and bank lending implied by Proposition 2:

$$
\begin{aligned}
& L_{m}=\int_{\theta^{*}}^{1} \int_{0}^{\infty}(1-\theta) I d F(\theta, I)=\int_{\theta^{*}}^{1}(1-\theta) E(I \mid \theta) d F(\theta), \\
& L_{b}=\int_{\bar{\theta}_{b}}^{\theta^{*}} \int_{0}^{\infty}(1-\theta) I d F(\theta, I)=\int_{\bar{\theta}_{b}}^{\theta^{*}}(1-\theta) E(I \mid \theta) d F(\theta),
\end{aligned}
$$

where $E(I \mid \theta)$ denotes the conditional expectation of $I$ given $\theta$, and $F(\theta)$ is the marginal cumulative distribution function of $\theta$. Total lending, $L$, is simply the sum of market and bank lending

$$
L=L_{m}+L_{b}=\int_{\bar{\theta}_{b}}^{1}(1-\theta) E(I \mid \theta) d F(\theta) .
$$

These quantities will play an important role in our discussion of the different strands of the literature on the credit channel.

\section{The Broad Credit Channel}

Much of the earlier work on the existence of a credit channel for the transmission of monetary policy focused on the correlations among aggregate output, bank and market debt, and indicators of monetary policy. More recently, the discussion has extended to more disaggregated data in other to show the impact of monetary policy on specific classes of borrowers. We start the analysis of the impact of monetary policy in the context of our simple model by looking at the effects of changes in the market interest rate $R$ on the critical values $\bar{\theta}_{b}$ and $\theta^{*}$ that define the ranges of bank and market finance, as well as on the aggregate quantities of bank and market lending.

\footnotetext{
${ }^{10}$ Other comparisons between the rates paid by market and bank borrowers (for instance, average rates) depend on the characteristics of the distribution of entrepreneurs.
} 
Abstracting from the difficulties involved in specifying a fully consistent model of a monetary economy, we interpret $R$ as the interest rate targeted by a monetary authority. So, changes in $R$ account for the short-run effects of (unanticipated) monetary policy actions. ${ }^{11}$

Proposition 3 An increase in the market interest rate $R$ increases the net worth ratio $\bar{\theta}_{b}$ at which bank finance becomes feasible and the net worth ratio $\theta^{*}$ at which entrepreneurs switch from bank to market finance. As a result, market lending, $L_{m}$, and total lending, L, go down. Moreover, if

$$
E\left(I \mid \bar{\theta}_{b}\right) F^{\prime}\left(\bar{\theta}_{b}\right)>E\left(I \mid \theta^{*}\right) F^{\prime}\left(\theta^{*}\right) .
$$

bank lending, $L_{b}$, also goes down.

Proof From (5) we get

$$
\frac{d \bar{\theta}_{b}}{d R}=\frac{1-\bar{\theta}_{b}}{R}>0
$$

On the other hand, Proposition 2 implies that the critical value $\theta^{*}$ is defined either explicitly by $\theta^{*}=\bar{\theta}_{m}$, if $u_{m}\left(\bar{\theta}_{m}\right)>u_{b}\left(\bar{\theta}_{m}\right)$, or implicitly by the condition $u_{m}\left(\theta^{*}\right)=$ $u_{b}\left(\theta^{*}\right)$, otherwise. In the first case we directly have

$$
\frac{d \theta^{*}}{d R}=\frac{1-\theta^{*}}{R}>0
$$

In the second case, the implicit function theorem gives the same final expression as in (17). These results together with the definitions (12)-(14) imply

$$
\begin{gathered}
\frac{d L_{m}}{d R}=-\frac{1}{R}\left(1-\theta^{*}\right)^{2} E\left(I \mid \theta^{*}\right) F^{\prime}\left(\theta^{*}\right)<0, \\
\frac{d L}{d R}=-\frac{1}{R}\left(1-\bar{\theta}_{b}\right)^{2} E\left(I \mid \bar{\theta}_{b}\right) F^{\prime}\left(\bar{\theta}_{b}\right)<0,
\end{gathered}
$$

and

$$
\frac{d L_{b}}{d R}=\frac{d L}{d R}-\frac{d L_{m}}{d R}
$$

\footnotetext{
${ }^{11}$ It is worth noting that monetary policy shocks would have no effect on lending in the absence of the moral hazard problem. Specifically, if $p$ were contractible, our Assumption 2 would imply that all entrepreneurs (regardless of their net worth ratio) would undertake their projects using market finance under a common borrowing rate. Hence aggregate lending and investment would be insensitive to small changes in $R$.
} 
whose sign is ambiguous in general. However, (15) is a sufficient condition for $d L_{b} / d R<0$, since $\left(1-\bar{\theta}_{b}\right)^{2}>\left(1-\theta^{*}\right)^{2}$

Proposition 3 implies that a tightening of monetary policy produces a flight to quality (i.e., a shift towards higher net worth borrowers) on the part of both market and bank lenders. ${ }^{12}$ Intuitively, a higher opportunity cost of capital tightens the lenders' participation constraint (2), which in turn worsens the entrepreneurial moral hazard problem. In terms of Figure 2 , the increase in $R$ moves both $\bar{\theta}_{b}$ and $\theta^{*}$ to the right. The effect on $\bar{\theta}_{b}$ directly relates to how $R$ affects the feasibility of finance for the bank borrower of lowest quality. The less obvious result on $\theta^{*}$ follows from the fact that $u_{m}(\theta)$ shifts down more than $u_{b}(\theta)$, because the worsening of the moral hazard problem is more severe under market finance. These predictions are consistent with the empirical findings that small, typically bank-dependent, less liquid, and less capitalized firms suffer the most from a tightening of monetary policy. ${ }^{13}$

As for the effects on credit aggregates, Proposition 3 implies that if the total investment by the lowest quality firms that borrow from banks is greater than the total investment by the lowest quality firms that borrow from the market, then a tightening of monetary policy reduces all credit aggregates as well as aggregate investment. Otherwise, the fall in investment, market lending, and total lending is unambiguous, but bank lending may increase due to the inflow of borrowers that abandon market finance.

One can easily check that a tightening of monetary policy increases the spreads between the borrowing rates, $B_{m}(\theta)$ or $B_{b}(\theta)$, and the market interest rate $R$, since the negative incentive effect of a larger $R$ reduces the probability of success of all projects. To the extent that aggregate investment is directly related to future output, this positive effect of $R$ on equilibrium spreads, together with its negative effect on aggregate investment, is consistent with the predictive content in real output

\footnotetext{
${ }^{12}$ For recent evidence on the importance of this flight to quality, see Bernanke, Gertler and Gilchrist (1996), and Lang and Nakamura (1995).

${ }^{13}$ Gertler and Gilchrist (1994) and Oliner and Rudebusch (1995) measure the cross sectional incidence of the broad credit channel using the fact that small firms tend to have a lower net worth ratio than large firms. They provide evidence of the significantly greater response of small firms to monetary policy shocks. Similarly Oliner and Rudebusch (1996a) show that the sensitivity of investment to cash flow is larger among small firms. In a more direct test, Gilchrist and Zakrajsek (1995) find that the response of inventory investment to cash flow increases monotonically across the four leverage categories they consider.
} 
equations of the spread between the commercial paper rate and the Treasury bill rate (Stock and Watson, 1989; Friedman and Kuttner, 1992).

Looking at the behavior of the aggregate quantities of short-term bank loans and commercial paper, Kashyap, Stein, and Wilcox (1993), henceforth KSW, found that a tightening of monetary policy reduces bank lending $L_{b}$, but in contrast with the predictions of our model increases market lending $L_{m}$. They also found that a tightening of monetary policy decreases what they called the financing mix variable $\mu=L_{b} / L$, that is, the fraction of short-term credit that comes from bank loans. In the context of our model, (18) and (19) imply

$$
\frac{d \mu}{d R}=\frac{1}{L}\left[(1-\mu) \frac{d L}{d R}-\frac{d L_{m}}{d R}\right]
$$

whose sign is ambiguous in general. However, when $\mu$ is sufficiently large we get $d \mu / d R>0$. These results suggest that the evidence reported by KSW cannot be explained in full with our simple model of the broad credit channel, and support their interpretation that a distinct bank lending channel may be in operation. Nevertheless the evidence in KSW is still controversial. In particular, the literature thereafter has pointed out that the observed behavior of short-term credit may relate to crosssectional differences in inventory policies and the recourse to trade credit which can only be properly controlled for using more disaggregated data. ${ }^{14}$

\section{The Bank Lending Channel}

The literature on the existence of a bank lending channel stresses that monetary shocks influence real economic activity, in part, by especially affecting the availability of bank credit. This view builds upon two key hypothesis: $\left(\mathrm{H}_{1}\right)$ monetary shocks cause larger shifts in the supply of bank loans than in the supply of other forms of credit, and $\left(\mathrm{H}_{2}\right)$ borrowers cannot costlessly replace bank loans with other forms of credit. Researchers have typically taken both hypothesis for granted rather than deriving them from first principles. ${ }^{15}$

\footnotetext{
${ }^{14}$ Gertler and Gilchrist (1993) and Oliner and Rudebusch (1996b) show that monetary contractions since the mid-1970s have prompted a reallocation of credit toward large firms but not a significant shift in the mix variable for either small or large firms.

${ }^{15}$ See, for example, the models in Bernanke and Blinder (1988) and KSW.
} 
Our benchmark model already delivers $\mathrm{H}_{2}$, but its perfectly elastic supply of market and bank lending cannot produce $\mathrm{H}_{1}$. The purpose of this section is to extend the model in two directions which may yield $\mathrm{H}_{1}$ : deposit interest rate ceilings and capital requirements. ${ }^{16}$ Both regulations have often been mentioned as possible causes of a distinct reaction of the supply of bank loans to a tightening of monetary policy. We want to examine whether their presence changes the comparative static results derived in the previous section.

To start with, consider a variation of our model in which the rates of return required by banks $\left(R_{b}\right)$ and market lenders $\left(R_{m}\right)$ can differ. When they are sufficiently close, the characterization of the regions of bank and market finance is identical to that derived before, with a minimum net worth ratio $\bar{\theta}_{b}$, increasing in $R_{b}$, for which bank finance is viable, and a net worth ratio $\theta^{*}$, decreasing in $R_{b}$ and increasing in $R_{m}$, for which entrepreneurs switch from bank to market finance. From here we can define the functions

$$
\left.\underset{-+}{L_{b}\left(R_{b}, R_{m}\right.}\right), \underset{+}{L} L_{m}\left(R_{b}, R_{m}\right), \text { and } \underset{-}{L\left(R_{b}\right)}
$$

that describe the behavior of bank, market, and total lending, respectively. ${ }^{17}$

Notice that if a tightening of monetary policy induces a greater increase in $R_{b}$ than in $R_{m}$, then it may be possible to get a reduction in the critical value $\theta^{*}$. Consistent with the findings in KSW, this would imply an increase in market lending $L_{m}$ and a decrease in the financing mix variable $\mu=L_{b} / L$. The following variations of our model attempt to explain why $R_{m}$ and $R_{b}$ can differ and can also be differently affected by monetary shocks.

\subsection{Deposit interest rate ceilings}

Assume that bank finance is exclusively provided by a class of perfectly competitive financial intermediaries which can only raise funds in the form of bank deposits $D$ (and, for simplicity, have no capital). Bank deposits, unlike market securities, provide

\footnotetext{
${ }^{16}$ Informational asymmetries and agency problems affecting banks provide alternative (and more intrincate) avenues. For instance, the problem of bank panics in Bernanke (1983) or the moral hazard problem between banks and investors in Holmstrom and Tirole (1997).

${ }^{17}$ The signs below the arguments are those of the corresponding partial derivatives, which are immediate to derive.
} 
some transaction services. These services are valuable to some investors who may, consequently, accept a deposit rate, $R_{d}$, below the expected rate of return of market securities, $R_{m}$. Moreover, assume that $R_{m}=R$, where $R$ is the interest rate targeted by the monetary authority. If $R_{d}<R$, banks face a supply of deposits which is represented by a function $D\left(R_{d}, R\right)$, increasing in $R_{d}$ and decreasing in $R$. In contrast, if $R_{d}=R$, they access the whole market supply of funds, which is perfectly elastic at the rate $R$. Suppose, however, that regulation establishes a binding ceiling $\bar{R}_{d}<R$ on the deposit rate.

Banks can provide both market finance and bank loans. If the supply of bank deposits $D\left(\bar{R}_{d}, R\right)$ is greater than the demand for bank loans at $R_{b}=R$, banks will use their excess funds to provide market finance. Otherwise they will only provide bank loans and we will have $R_{b}>R$, reflecting the scarcity of banks' loanable funds. In particular, $R_{b}$ will be determined by the equilibrium condition:

$$
D\left(\bar{R}_{d}, R\right)=L_{b}\left(R_{b}, R\right)
$$

In this case, if following a tightening of monetary policy (an increase in $R$ ) the ceiling $\bar{R}_{d}$ remains unchanged, investors will reduce their supply of deposits and banks will be forced to cut down their loans by the same amount. The magnitude of the reduction in $L_{b}$ will only depend on the elasticity of the supply of deposits to the market interest rate $R$. Therefore, if investors' substitutability between bank deposits and market securities is sufficiently high, the wedge between $R_{b}$ and $R$ will increase and consequently $\theta^{*}$ may fall. Thus, the existence of interest rate ceilings may lead to an increase in the issuance of market securities during episodes of tight money, so it provides a candidate explanation for the findings of KSW. Supporting this interpretation, Friedman and Kuttner (1993b) document that the behavior of commercial paper in the last two recessions (when Regulation $Q$ interest rate ceilings were no longer in place) did not follow the average post-war pattern highlighted by $\mathrm{KSW} \cdot{ }^{18}$

If we were to relax the assumption that banks can only raise funds in the form of core (interest rate regulated) deposits - for example, if banks were able to issue

\footnotetext{
${ }^{18}$ Under Regulation $Q$, ceilings on deposit rates were sometimes used for monetary policy purposes. Equation (20) allows us to examine the impact of a reduction in $\bar{R}_{d}$. Deposit supply will fall, forcing banks to cut their lending. Consequently, $R_{b}$ will go up, so $\bar{\theta}_{b}$ will increase and $\theta^{*}$ will decrease. Hence market lending will increase, and bank lending, total lending, and investment will fall.
} 
certificates of deposit (CDs) at the market interest rate $R$-, the equilibrium would be the same as in our initial model, except that now banks would be able to cover part of their intra-marginal financing with cheap deposits, thus earning a rent. One can argue, however, that financial imperfections at the level of the banks may impede them to access a perfectly elastic demand for CDs (see Kashyap and Stein, 1995). In such case, the level of core deposits would be relevant to determine the banks' marginal cost of funds, and the qualitative results derived in this section would still hold.

\subsection{Capital requirements}

Suppose now that deposit interest rate ceilings are not in place but banks are subject a capital adequacy requirement. In particular, they are obliged to fund a fraction $\gamma$ of their lending with their own capital $K$. Moreover, assume for simplicity that the supply of bank deposits is perfectly elastic at the interest rate $R$, and consider a short-run situation in which banks are endowed with a fixed amount of capital $\bar{K}$. In this situation, banks' capacity to lend is bounded by $\bar{K} / \gamma$. If the demand for bank loans at $R_{b}=R$ is greater than this bound, the capital requirement will be binding, banks will only provide bank loans, and we will have $R_{b}>R$. Specifically, $R_{b}$ will be determined by the equilibrium condition:

$$
\bar{K} / \gamma=L_{b}\left(R_{b}, R\right)
$$

From this expression, it follows that binding capital requirements alter the transmission of monetary policy shocks. Most importantly, the total amount of bank lending $L_{b}$ is determined by $\bar{K} / \gamma$, so it does not depend on $R$. Nevertheless, changes in $R$ have both distributional and aggregate effects. For a given $R_{b}$, the first reaction to an increase in $R$ will be that the least capitalized firms getting market finance will want to shift to bank finance. As bank lending capacity is limited, this will generate an upward pressure on $R_{b}$, raising $\bar{\theta}_{b}$. The result is a flight to quality up to the point where the amount of bank loans lost in the lower tail of the distribution of net worth ratios equals the amount gained in the upper tail. At the aggregate level, market lending, total lending, and investment will fall, whilst bank lending will remain unchanged. Thus, binding capital requirements make bank lending (and investment) 
less sensitive to changes in $R$ (an effect noted by Kashyap and Stein, 1994), but they cannot directly explain the KSW results. ${ }^{19}$

However, capital requirements create new sources of fluctuations in credit aggregates. In particular, from (21), a fall in $\bar{K}$ or an increase in $\gamma$ will produce a credit crunch: bank lending and investment will fall, and the highest quality bank borrowers will shift to market finance. ${ }^{20}{ }^{21}$ This is important since there are reasons to think that short-run fluctuations in $\bar{K}$ are not independent of monetary policy. Some longterm bank assets entail fixed interest rates whereas the returns of many short-term bank liabilities are closely linked to market interest rates. Increases in $R$ in such an environment will generate losses to the banks, thereby reducing $\bar{K}$ and hence their capacity to lend. It is also well documented that banks' profits deteriorate at the outset of recessions as a result of the increase in default rates. In a world of binding capital requirements, banks' lending capacity would consequently decline. For these reasons, movements in bank capital might also provide an explanation for the decline of bank loans relative to market lending during episodes of tight money.

\section{Conclusion}

We have developed a model of the choice between market and bank lending in order to provide a framework for analyzing the different strands of the credit view of the transmission of monetary policy. The model is based on a simple moral hazard problem between entrepreneurs and their lenders that banks can ameliorate through monitoring. We have characterized a credit market equilibrium in which firms with high net worth ratios prefer market lending, those with intermediate net worth get bank lending, and those with little net worth are unable to borrow.

The analysis of the response of this equilibrium to changes in the stance of monetary policy has identified the main implications of a broad credit channel for monetary

\footnotetext{
${ }^{19}$ The financing mix variable $\mu=L_{b} / L$ will increase rather than decrease after a rise in $R$.

${ }^{20}$ Recent events seem to illustrate this possibility. For example, the decline of bank lending in the US during the months preceding the cyclical peak of 1990 has been related to the rise in capital requirements in 1989 (see Bernanke and Lown, 1991).

${ }^{21}$ Holmstrom and Tirole (1997) obtain this result in a model where a minimum investment of banks' own funds is necessary for bankers to have incentives to monitor their borrowers, so "capital requirements" are endogenous.
} 
transmission. A tightening of monetary policy (i) reduces aggregate investment, as well as the amounts of market and (under certain conditions) bank lending, (ii) widens the spreads between the interest rates charged to the borrowers and the riskless interest rate, and (iii) produces a flight to quality, i.e. a shift towards higher net worth borrowers. These results seem broadly consistent with the evidence, although they fail to produce a rise in market lending during monetary contractions. When the model is extended to incorporate the possible causes of a distinct bank lending channel, we find that deposit interest rate ceilings like those of Regulation $Q$ can explain this behavior. On the other hand, capital requirements may only explain it if monetary contractions are followed by declines in bank capital.

Overall, the mechanisms underlying the broad credit channel seem fairly robust, and the empirical evidence at both the macro and the micro level supports their relevance. Our model is able to capture these mechanisms at the cost of great simplification. Further research in this area should aim at surmounting the main limitations of our analysis. In particular, its static partial equilibrium nature and the assumption, related to the difficulties of specifying a fully consistent model of a monetary economy, that monetary policy acts directly on the riskless interest rate. 


\section{References}

[1] Bernanke, Ben S. (1983), "Nonmonetary Aspects of the Financial Crisis in the Propagation of the Great Depression", American Economic Review, 73, pp. 257276.

[2] Bernanke, Ben S., and Blinder, Alan (1988), "Credit, Money, and Aggregate Demand", American Economic Review (Papers and Proceedings), 78, pp. 435439.

[3] Bernanke, Ben S., and Gertler, Mark (1989), "Agency Costs, Net Worth, and Business Fluctuations", American Economic Review, 79, pp. 14-31.

[4] Bernanke, Ben S., Gertler, Mark, and Gilchrist, Simon (1996), "The Financial Accelerator and the Flight to Quality", Review of Economics and Statistics, 78, pp. 1-15.

[5] Bernanke, Ben S., and Lown, Cara (1991), "The Credit Crunch", Brookings Papers on Economic Activity, 2, pp. 205-239.

[6] Besanko, David, and Kanatas, George (1993), "Credit Market Equilibrium with Bank Monitoring and Moral Hazard", Review of Financial Studies, 6, pp. 213232.

[7] Bhattacharya, Sudipto, and Chiesa, Gabriella (1995), "Proprietary Information, Financial Intermediation, and Research Incentives", Journal of Financial Intermediation, 4, pp. 328-357.

[8] Diamond, Douglas (1984), "Financial Intermediation and Delegated Monitoring", Review of Economic Studies, 51, pp. 393-414.

[9] Diamond, Douglas (1991), "Monitoring and Reputation: The Choice between Bank Loans and Directly Placed Debt", Journal of Political Economy, 99, pp. 689-721.

[10] Friedman, Benjamin M., and Kuttner, Kenneth N. (1992), "Money, Income, Prices, and Interest Rates", American Economic Review, 82, pp. 472-492. 
[11] Friedman, Benjamin M., and Kuttner, Kenneth N. (1993a), "Economic Activity and the Short-Term Credit Markets: An Analysis of Prices and Quantities", Brookings Papers on Economic Activity, 2, pp. 193-266.

[12] Friedman, Benjamin M., and Kuttner, Kenneth N. (1993b), "Why Does the Paper-Bill Spread Predict Real Economic Activity?", in Stock, James H. and Watson, Mark W. (eds.), Business Cycles, Indicators and Forecasting, Chicago: The University of Chicago Press, pp. 213-249.

[13] Gertler, Mark (1988), "Financial Structure and Aggregate Economic Activity: An Overview", Journal of Money, Credit and Banking, 20, pp. 559-588.

[14] Gertler, Mark, and Gilchrist, Simon (1993), "The Role of Credit Market Imperfections in the Monetary Transmission Mechanism: Arguments and Evidence", Scandinavian Journal of Economics, 95, pp. 43-64.

[15] Gertler, Mark, and Gilchrist, Simon (1994), "Monetary Policy, Business Cycles, and the Behavior of Small Manufacturing Firms", Quarterly Journal of Economics, 109, pp. 309-340.

[16] Gilchrist, Simon, and Zakrajsek, Egon (1995), "The Importance of credit for Macroeconomic Activity: Identification through Heterogeneity", in Peek, Joe, and Rosengren, Eric (eds.), Is Bank Lending Important for the Transmission of Monetary Policy?, FRB of Boston, Conference Series No. 39, pp. 129-158.

[17] Greenwald, Bruce C., and Stiglitz, Joseph E. (1993), "Financial Market Imperfections and Business Cycles", Quarterly Journal of Economics, 108, pp. 77-114.

[18] Holmstrom, Bengt, and Tirole, Jean (1997), "Financial Intermediation, Loanable Funds, and the Real Sector", Quarterly Journal of Economics, 112, pp. 663-691.

[19] Hubbard, R. Glenn (1995), "Is There a 'Credit Channel' for Monetary Policy?", Federal Reserve Bank of St. Louis Review, May/June, pp. 63-77.

[20] Kashyap, Anil K., and Stein, Jeremy C. (1994), "Monetary Policy and Bank Lending", in Mankiw, N. Gregory (ed.), Monetary Policy, Chicago: The University of Chicago Press, pp. 221-256. 
[21] Kashyap, Anil K., and Stein, Jeremy C. (1995), "The Impact of Monetary Policy on Bank Balance Sheets", Carnegie-Rochester Conference Series on Public Policy, 42, pp. 151-195.

[22] Kashyap, Anil K., Stein, Jeremy C., and Wilcox, David W. (1993), "Monetary Policy and Credit Conditions: Evidence from the Composition of External Finance", American Economic Review, 83, pp. 78-98.

[23] Kiyotaki, Nobuhiro, and Moore, John H. (1997), "Credit Cycles", Journal of Political Economy, 105, pp. 211-248.

[24] Lang, William W., and Nakamura, Leonard I. (1995), "Flight to Quality' in Banking and Economic Activity", Journal of Monetary Economics, 36, pp. 145164.

[25] Nakamura, Leonard I. (1993), "Commercial Bank Information: Implication for the Structure of Banking", in Klausner, Michael, and White, Lawrence W. (eds.), Structural Changes in Banking, Homewood, Ill: Business One/Irwin, pp. 131160 .

[26] Oliner, Stephen D., and Rudebusch, Glenn D. (1995), "Is There a Bank Lending Channel for Monetary Policy?", Federal Reserve Bank of San Francisco Economic Review, 2, pp. 3-20.

[27] Oliner, Stephen D., and Rudebusch, Glenn D. (1996a), "Is There a Broad Credit Channel for Monetary Transmission?", Federal Reserve Bank of San Francisco Economic Review, 1, pp. 3-13.

[28] Oliner, Stephen D., and Rudebusch, Glenn D. (1996b), "Monetary Policy and Credit Conditions: Evidence from the Composition of External Finance: Comment", American Economic Review, 86, pp. 300-309.

[29] Repullo, R., and Suarez, Javier (1998), "Monitoring, Liquidation, and Security Design", Review of Financial Studies, 11, pp. 163-187.

[30] Romer, Christina D., and Romer, David H. (1990), "New Evidence on the Monetary Transmission Mechanism", Brookings Papers on Economic Activity, 1, pp. 149-198. 
[31] Stock, James, and Watson, Mark (1989), "New Indexes of Coincident and Leading Economic Indicators", in Blanchard, Olivier J. and Fisher, Stanley (eds.), NBER Macroeconomics Annual 1989, Cambridge, MA: MIT Press, pp. 351-394.

[32] Suarez, Javier, and Sussman, Oren (1997), "Endogenous Cycles in a StiglitzWeiss Economy", Journal of Economic Theory, 76, pp. 47-71.

[33] Yosha, Oved (1995), "Information Disclosure Costs and the Choice of Financing Source", Journal of Financial Intermediation, 4, pp. 3-20. 
Utilitities

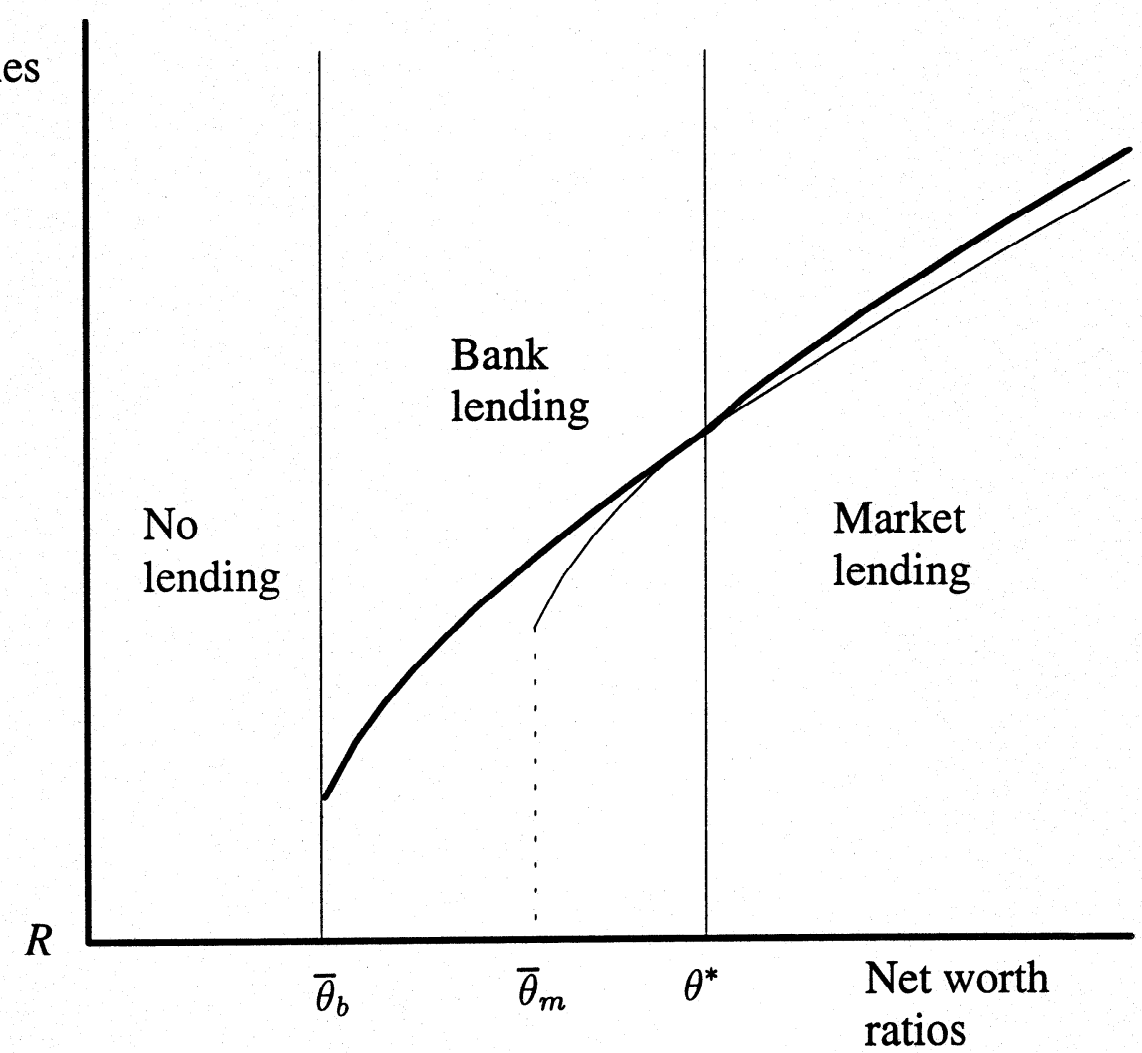

Figure 1. Utilities under Market and Bank Lending 


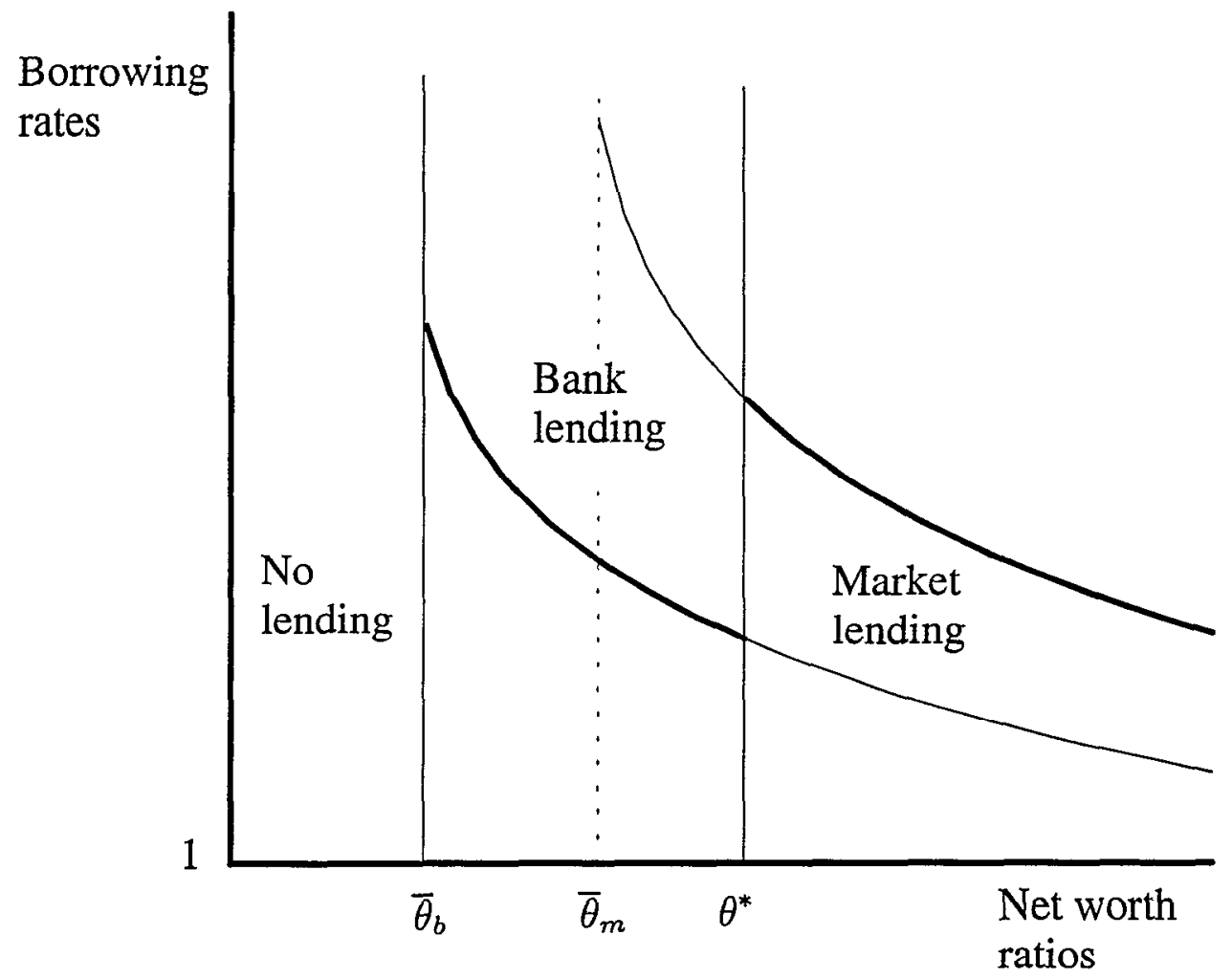

Figure 2. Equilibrium Borrowing Rates 